\title{
Cointegration and Causality Relationship Between Stock Market, Money Market and Foreign Exchange Market in Pakistan
}

\author{
Ghulam ABBAS* \\ School of Economics and Management, University of Chinese Academy of Sciences, Beijing 100190, \\ China; Sukkur Institute of Business Administration, Sindh-6500, Pakistan \\ E-mail:g.abbas.mba@hotmail.com;g.abbas@mails.ucas.ac.cn \\ Roni BHOWMIK \\ Academy of Mathematics and Systems Science, Chinese Academy of Sciences, Beijing 100190, China \\ E-mail:roni2024@yahoo.com \\ Laxmi KOJU \\ Academy of Mathematics and Systems Science, Chinese Academy of Sciences, Beijing 100190, China \\ E-mail: laxqouz@gmail.com \\ Shouyang WANG \\ Academy of Mathematics and Systems Science, Chinese Academy of Sciences, Beijing 100190, China; \\ School of Economics and Management, University of Chinese Academy of Sciences, Beijing 100190, \\ China \\ E-mail: sywang@amss.ac.cn
}

\begin{abstract}
This paper examines the relationship between stock market (KSE-100), money market (M2 and 180 days T-bill rate), and foreign exchange market (ER: PKR/USD) in Pakistan by using monthly data covering the period from 2000:M1 to 2015:M12. The study investigates long-run equilibrium relationship between these three financial markets by employing Johansen and Juselius ${ }^{[1]}$ cointegration tests. Long-run and short-run causality relationship between stock market and other macroeconomic variables is also established by employing vector error correction model (VECM) and pairwise granger causality tests. The results of multivariate cointegration test (trace test) indicate a one cointegrating vector, and the significant normalized cointegrating coefficients are evident of long run equilibrium relationship between all the selected variables. Negative and significant ECT $(-1)$ for all variables during full sample period witness the presence of long-run causality connection among variables, while during the military regime and democratic regime, significant difference of long-run causal connections are identified across the regimes. Moreover, the results of granger causality test also indicate that there are significant variations in the causality relationship among variables across the regimes. Therefore, it is essential for forecasting, planning and policy making to consider the importance of political governance system while analyzing the historical cointegration among financial market and make the necessary adjustments accordingly.
\end{abstract}

Keywords KSE-100 index; money supply; interest rate; exchange rate; Pakistan

Received October 11, 2016, accepted December 26, 2016

Supported by TWAS under the CAS-TWAS President Fellowship Program and Sukkur IBA

*The corresponding author 


\section{Introduction}

The dynamic relationship between stock market and money market is always remained an area of great interest for academicians, finance professionals and policy makers in both public and private sectors. Policy makers watch stock market movements very closely and make necessary adjustments in the interest rate to affect borrowing and investing decisions of investors. They use monetary policy as one of the most effective tools to regulate the stock market. The economic rationale of interrelationship between stock prices and monetary variables is primarily based on the efficient market hypothesis (EMH). According to EMH, asset prices reflect the arrival new information in the market about the securities. The reaction of asset prices to the changes in different economic variables in the market is not constant. Therefore, it is important to analyze the true reaction of asset prices to the changes in monetary variables like money supply, interest rate and exchange rate. Essentially, the indirect connection of asset prices to monetary variables is based on the expected cash flows and corporate earnings. Whereas, the corporate earnings reflect the behavior of macroeconomic variables, and any change in the macroeconomic variables will ultimately affect the profitability of the firms. Consequently, the asset prices will reflect the movements in macroeconomic variables that conduits through corporate earnings.

Specifically, the connection between money supply and stock prices can be viewed through inflationary expectations or real activity approach in the market. According to inflationary expectation approach propagated by Keynesian economists, an increase in money supply could have negative impact on stock prices due to high inflation rate in the economy that may lead to increase the interest rate. As a result, discount rates go up that would decrease the present value and expected cash flows of the firms that would further decrease the stock prices. Sellin ${ }^{[2]}$ further argued that economic activities decline as a result of increased interest rate that would further depress the stock prices. On the other hand, as perpetuated by real activity theorists, an increase in money supply means that there is more demand for money in the market due to increased economic activities. High economic activity is positively linked with the profitability of the firms. Consequently, the stock prices increase to high corporate earnings. Hence, the Keynesian economists proposed a negative relationship between money supply and stock prices, while real activity theorists offered a positive connection between these two variables.

Although, the relationship between stock market and monetary policy instruments is interdependent, but it is a very complicated dilemma to deal with. There are quite mixed results on the linkage between stock market and monetary policy variables reported by the previous studies $^{[3-5]}$. They found that central banks policy rate has negative relationship with the asset prices. It is further argued that investors make their rational choices to invest their money by comparing the rate of return that they will receive from both investing opportunities either in stock market or in money market. On the other hand, the studies of [6,7], showed no causal connection between policy rates and asset prices. Similarly, the studies of [8-12] explored the relationship between money supply and asset prices, and majority of them found a positive linkage between money supply and asset prices due to liquidity effect.

There are two schools of thought regarding the relationship between stock market and

monetary policy variables. First, the protagonists of proactive monetary policy ${ }^{[13-15]}$, and the 
second are the antagonists of proactive monetary policy ${ }^{[16,17]}$. The protagonists explain the fact that the booms and busts in the stock markets are very costly and create much distortion in the real economic activities, so, the policy makers and authorities should lower (increase) interest rates when assets prices are falling (rising) beyond the fundamental levels. Whereas, the antagonists of proactive monetary policy argue that it is very difficult to decide when to lower or increase the interest rates, and whether interest rate could stabilize the asset prices or not. Therefore, they propose a reactive approach to wait and see whether the asset prices reversal occurs or not, and then to react accordingly. In either case, it is quite possible that monetary policy and stock prices can have a close connection, and in one way or other, monetary policy can affect the asset prices.

In addition, exchange rate is also considered as one of the important macroeconomic factor that can strongly influence the asset prices. However, there are quite contrasting results reported in the previous literature on this nexus. Hasan and Javed ${ }^{[1]}$ reported a long-run equilibrium relationship between stock prices and exchange rate whereas Nieh and Lee ${ }^{[18]}$; Smyth and Nanda ${ }^{[19]}$ found a short term linkage between these two variables ${ }^{1}$. Moreover, there are quite mixed results in the previous literature on the nature and direction of relationship between stock prices and foreign exchange rate. For example, the studies of $[10,11,20]$ found a positive relationship between stock prices and exchange rate while $[21,22]$ reported a negative connection between these two variables. It is also widely reported in the literature that the causal relationship between exchange rate and stock market is either unidirectional ${ }^{[23]}$, or bidirectional ${ }^{[24]}$. Nonetheless, some of the studies ${ }^{[25,26]}$ found no evidence of causal relationship between stock market and exchange rate.

On the basis of foregoing discussion, the current study focuses on the predominant causal connections between stock market, money market and foreign exchange market in Pakistan. In this study, KSE-100 index represent the stock market, interest rate and money supply represent money market, while exchange rate (PKR/USD) represent the foreign exchange market. The main motivation of this research is to analyze the linkages between stock market, money market and foreign exchange market under the different political regimes in Pakistan ${ }^{2}$. The political history of Pakistan has always remained very vulnerable, and it is not a positive sign for both local and foreign investors. The results could be misleading if the policy makers ignore the past performance of financial markets during the previous politically instable governance regimes. Therefore, it is quite imperative to analyze the connection between stock market, money market and foreign exchange market under different political regimes (military regime and democratic

\footnotetext{
${ }^{1}$ Hasan and Javed ${ }^{[11]}$ applied multivariate cointegration test and granger causality test in their study on Pakistan. They found both long-run and short run causal connection between stock market and exchange rate. Yau and Nieh ${ }^{[27]}$ also discovered a long-run equilibrium relationship between exchange rate and stock market in case of Japan and Taiwan. Mishra ${ }^{[28]}$ found a short term granger causality relationship between stock market and exchange rate for India.

${ }^{2}$ Since January 2000 to December 2015, Pakistan is governed by military and democracy leadership both. The military leadership took over the charge with October 1999 coup, and formally the chief of army staff Gen. Pervaiz Musharaf became the president of Pakistan in June 2001 and his tenure ended in August 2008. We have considered this regime as Military regime that starts from January 2000 to July 2008. The second regime of our sample time period consists on Democracy governance that starts from August 2008, and it is still in progress. We term this regime as democratic regime that covers the period from August 2008 to December 2015.
} 
government). We find quite varying results about the interrelationship between these three markets across different regimes.

This study is aimed to analyze the long term co-movement and causality linkage among money market, stock market and foreign exchange market in Pakistan. This study contributes in two different ways; first, it examines the long-run equilibrium relationship between stock market, money market and foreign exchange market under the different political regimes. Second, we also estimate long run and short run causality relationship between the stock price and other monetary variables included in this study under the three different sub-samples. The study finds significant differences in the relationship between stock prices, money supply, interest rate and exchange rate across the political regimes in Pakistan. Furthermore, as a robust check, we also estimate a multivariate linear regression model that justifies the nature of relationship with partial differences. This study will make a significant contribution in the existing literature on Pakistan and the results will be useful for policy makers and financial analysts in the field of economics and finance.

\section{Literature Review}

Money market and foreign exchange market are noted as the fundamental factors of stock market movement. The investigation about the relationship between these markets has remained an area of prime interest for the researchers and policy makers. A significant body of literatures has been put forward so for on the long-run equilibrium relationship and causal connection between stock market and macroeconomic variables. Humpe and Macmillan ${ }^{[29]}$ explained that there can be two ways to establish the linkage between macroeconomic variables and stock prices. One way is Arbitrage Pricing Theory (APT) in which multiple risk factors are taken into account in order to explain asset returns. According to this approach, volatility in macroeconomic variables can be reflected in the underlying systematic risk factor that influences the future stock returns. Another approach used by Chen, et al. ${ }^{[30]}$ is Present Value Model (PVM) framework that also explains the impact of macroeconomic variables volatility upon stock returns. The main advantage of this approach in comparison to APT is that it focuses on the long-run relationship between stock prices and macroeconomic variables. But most of the empirical work ${ }^{[31-36]}$ are based on APT have modeled a short run relationship between stock prices and macroeconomic variables.

The empirical results about the causal connection between money supply, interest rate, exchange rate and stock market prices/returns are entirely muddled up. For example, Hashemzadeh and Taylor ${ }^{[37]}$ found a feedback causal relationship from S\&P-500 to money supply but they mentioned that money supply and interest rate are not the good predictors of stock market while Malliaris and Urrutia found a causal links between money supply and S\&P-500, where money supply leads the stock market and stock market leads the economic activity. Mukherjee and Naka ${ }^{[10]}$ also examined the long-run equilibrium relationship between stock market and macroeconomic variables (money supply, industrial production, exchange rate, inflation, long term government bond rates, and call money rate) for Japan. By employing vector error correction model (VECM) on monthly data, they found a significant evidence of positive connection

between money supply and stock market. Similarly, many other studies ${ }^{[20,38,39]}$ also reported 
a positive connection between money supply and stock prices. While discussing a causal relationship between money supply and stock prices, Shostak ${ }^{[40]}$ argued that an increase in stock prices also provide an incentive to liquidate the fixed income securities and use that money to buy stocks and other financial assets. Thus, the demand deposits will increase that in turn increases the money supply. This trend can be reversed if stock prices fall. He further argues that causality cannot be achieved only by statistical figures without having a coherent definition of what money is and how it is related to stock prices and other financial assets.

In case of Pakistan, Hasan and Javed ${ }^{[11]}$ established a long-run equilibrium relationship between monetary variables (money supply, treasury bill rate, consumer price index, and exchange rate) and equity prices by employing multivariate cointegration approach on monthly data covering from 1998:M6 to 2008:M6. They also employed granger causality test and VAR model (impulse response functions) to analyze the short term causal relationship between the selected variables. The results of multivariate Johansen and Juselius ${ }^{[1]}$ cointegration test indicate a long-run equilibrium relationship between variables, while granger causality test indicates a unidirectional causality moving from monetary variables to equity prices. Moreover, the results of impulse response function are evident of positive relationship between money supply and equity prices while it is negative for interest rate and exchange rate. By using quarterly data, Abbas and McMillan ${ }^{[12]}$ also established a long-run equilibrium between stock market index and monetary variables for Pakistan. Humpe and Macmillan ${ }^{[29]}$ among others reported a negative relationship between stock prices and interest rate for Japan and US. Conversely, Ratanapakorn and Sharma ${ }^{[20]}$ found a positive relationship between short-term interest rate and stock prices for USA. Some of the studies ${ }^{[6,7,41]}$ found no causal connection between stock prices and interest rate.

In case of exchange rate, the studies of $[10-12,20]$ among others found a long-run equilibrium relationship between exchange rate and stock prices. For feedback causal connection between exchange rate and stock prices in US, Bahmani-Oskooee and Sohrabian ${ }^{[42]}$ found that there is a bidirectional causality between exchange rate and stock prices in short run, whereas, Choi, et al. ${ }^{[43]}$ and $\mathrm{Kim}^{[21]}$ claimed a negative and unidirectional causality relationship between exchange rate and stock prices that move from exchange rate to stock prices. Dominguez and Tesar ${ }^{[4]}$ also mentioned that exchange rate fluctuations have a significant impact on the equity prices at firm level and sectoral level for developed economies. Similarly, Chkili and Nguyen ${ }^{[45]}$ examined the relationship between exchange rate and stock returns for BRICS countries by employing regime switching approach. They discovered that exchange rate movement has no effect on stock returns while stock returns have a significant impact of exchange rate changes except South Africa. Lee, et al. ${ }^{[46]}$ examined the relationship between exchange rate and stock prices for Asia-Pacific economies by employing dynamic correlation approach. They found that the correlation between stock market and exchange rate becomes higher as stock market volatility increases. For the same countries, Yang, et al. ${ }^{[47]}$ reported a negative correlation between exchange rate and stock market. Similarly, Moore and Wang ${ }^{[22]}$ also found a negative relationship between exchange rate and stock prices. Hasan and Javed ${ }^{[1]}$ studied the causality relationship between these two variables and found a positive and unidirectional causality moving from exchange rate to stock prices in short run. Based on the literature review and the objectives of 
this study, we investigate the long-run equilibrium relationship between stock market, money market and stock market in case of all three sample periods. Moreover, we also investigate the short run granger causality relationship between all three markets in full sample period, military regime and democratic regime.

\section{Data and Descriptive Summary}

Monthly data covering from 2000:M1 to 2015:M12 has been used in this study to investigate the relationship among stock market, money market and foreign exchange market in case of Pakistan. KSE-100 index has been used as a proxy measure for stock prices in the in Pakistan 90 days T-bill rate and M2 are used as a measure of short term interest rate and money supply. By using monthly data, Wong, et al. ${ }^{[48]}$ also studied the cointegration relationship between interest rate, money supply and stock prices for USA and Singapore. The exchange rate (PKR/USD) is used as an explanatory variable in this study in analyze the impact of external shock on local markets ${ }^{[49]}$ among others uses monthly data for the emerging Asian economies to investigate the relationship between stock prices and exchange rate. The data for all these variables has been collected from the CEIC global database ${ }^{3}$. In order to stabilize the data, all the series are used in the log form except T-bill rate and their time series plots are shown in Figure 2. Maysami, et al. ${ }^{[50]}$ have also used monthly data for Singapore to analyze the relationship between macroeconomic variables and stock market indices, and they found that it gives more robust results than quarterly or daily data.

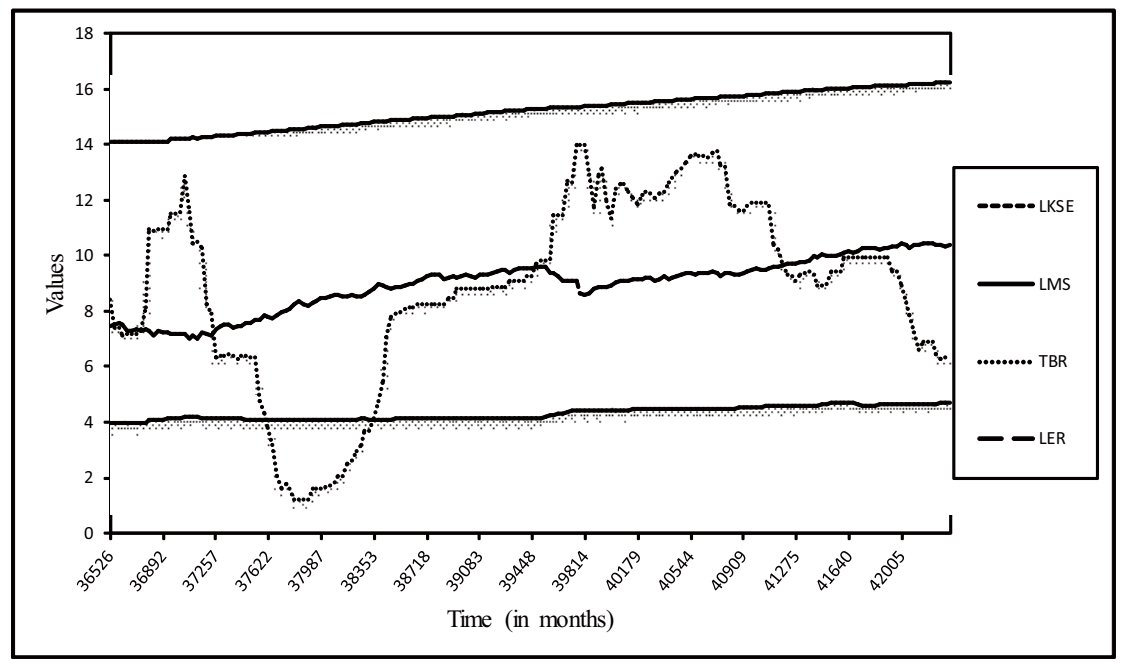

Figure 1 Time series plot of KSE-100 index, interest rate, money supply and exchange rate

The results of descriptive statistics are presented in Table 1. These statistics explain the basic features of the logged variables like mean, standard deviations, minimum and maximum,

\footnotetext{
${ }^{3} \mathrm{CEIC}$ is a European institutional investor company founded in 1992 that provides most expansive and accurate economic and financial data about the emerging and developed markets. The CEIC global database was accessed from the School of Management, University of Chinese Academy of Sciences, Beijing, China.
} 
skewness and kurtosis and Jarque-Bera test-statistic. The results show that the value of standard deviation for KSE-100 index is greater than the other three variables which indicate that Pakistan stock market is quite risky as compared to other macroeconomic variables. The results also indicate that except KSE-100 index, all the other variables are negatively skewed and kurtosis result shows that the distribution of all variables is fatter tailed Jarque-Bera teststatistic for all the variables is significant that indicates that all the variables are not normally distributed.

Table 1 Summary of descriptive statistics and correlation matrix

\begin{tabular}{ccccc}
\hline & KSE-100 & TBR & M2 & ER \\
\hline Mean & 8.9784 & 15.2022 & 8.8192 & 4.2854 \\
Maximum & 10.4681 & 16.2430 & 14.0100 & 4.6776 \\
Minimum & 7.0330 & 14.0818 & 1.2100 & 3.9472 \\
Std. Dev. & 0.9560 & 0.6544 & 3.3424 & 0.2315 \\
Skewness & -0.4843 & -0.1191 & -0.6659 & 0.2950 \\
Kurtosis & 2.2884 & 1.7863 & 2.7987 & 1.4833 \\
Jarque-Bera & $11.5566^{*}$ & $12.2391^{*}$ & $14.5141^{*}$ & $21.1882^{*}$ \\
Prob. & $(0.0031)$ & $(0.0022)$ & $(0.0007)$ & $(0.0000)$ \\
Observations & 192 & 192 & 192 & 192 \\
\hline
\end{tabular}

Note KSEI-100 stands for Karachi Stock Exchange Index, M2 for money supply, TBR for short term Interest rate and ER for exchange rate (PKR/USD), $p$-value in ( ), *significant at $\alpha=1 \%$. Source: The results presented in Table 1 are author's own estimates based on the CEIC global database.

\section{Methodology}

In the time series data, presence of long-run equilibrium relationship between non-stationary variables is one of the core concerns of economists. Granger ${ }^{[51]}$, and Engle and Granger ${ }^{[52]}$ introduced the concept of "cointegration" to capture the relationship of such nature. Stock ${ }^{[53]}$ investigated that if two series say $Y_{t}$ and $X_{t}$ are non-stationary and highly cointegrated, then they would produce highly efficient and consistent estimates of the parameters. If in the time series data two variables have common trend, then they are more likely to have long-run relationship between them. So in order to check the nature of trend in variables, cointegration tests are important. A significant body of literature [48,54-56] discussed the details of this concept of cointegration. In order to analyze the long term co-movement of KSE-100 index, money supply (M2), Interest rate (6 months T-bill rate) and exchange rate (PKR/USD), a variety of cointegration tests may be used. In this study, we use a multivariate approach developed by Johansen and Juselius ${ }^{[1,57]}$ to capture the equilibrium relationship between stock market index and financial economic variables.

The first step in the empirical analysis is to check the stationarity of variables by using unit root test procedure developed by Dickey-Fuller ${ }^{[58,59]}$. Any of the series, say $Z_{t}$ is said to be integrated of order " $d$ " if it has stationarity and stochastic ARMA at differencing " $d$ " times and it is denoted by $Y_{t}=I(d)$. Most of the non-stationary financial variables are integrated of 
order $I(1)$, but if they are stationary and integrated at zero difference then they are denoted by $I(0)$. Suppose there are two variables say, $Y_{t}$ and $X_{t}$ are integrated at $I(1)$ then the regression equation (1) is used to estimate the long-run equilibrium relationship between variables, and further stationarity tests are used to test the stationarity of estimated residuals. If the variables are not cointegrated, then the estimated residuals will be integrated at order $I(1)$, otherwise the residuals will be stationary and integrated at order $I(0)$. Moreover, the regression results of non-stationary series will be spurious and misleading and the residuals will not be $I(0)$ in such conditions.

$$
Y_{t}=\beta_{0}+\beta_{1} X_{t}+e_{t}
$$

here in Equation (1) $e_{t}$ is the estimated residuals of these time series variables and two most common tests of stationarity Augmented Dickey-Fuller (ADF) and Phillips-Perron (PP) are used to check the stationarity of these estimated residuals

As we have more than two variables in the model, so, there is a possibility of having more than one integrating vector. It means that the variables in the model might form several equilibrium relationships governing the joint evolution of all the variables. In general, for $n$ number of variables we can have only up to $n-1$ cointegrating vectors. Therefore, when $n=4$, then this is very serious problem which cannot be resolved by simple single equation approach. Therefore, an alternative approach is needed and this is multiple equations approach developed by Johansen and Juselius ${ }^{[1]}$.

This approach can be presented by extending the single equation error correction model to a multivariate one. Suppose, there are three endogenous variables, say $W_{t}, X_{t}$ and $Z_{t}$ then we can have (using matrix notation for $Y_{t}=\left[W_{t}, X_{t}, Z_{t}\right]$ )

$$
Y_{t}=A_{1} Y_{t-1}+A_{2} Y_{t-2}+\cdots+A_{k} Y_{t-k}+u_{t}
$$

Equation (2) is comparable to the single equation dynamic model (1) of two variables of $Y_{t}$ and $X_{t}$. Further, Equation (2) can be reformulated in a vector error correction model (VECM) as follows:

$$
\Delta Y_{t}=\Gamma_{1} \Delta Y_{t-1}+\Gamma_{2} \Delta Y_{t-2}+\cdots+\Gamma_{k} \Delta Y_{t-k-1}-\Pi Y_{t-1}+u_{t}
$$

where $\Gamma_{i}=\left(I-A_{1}-A_{2}-\cdots-A_{k}\right)(i=1,2, \cdots, k-1)$ and $\Pi=-\left(I-A_{1}-A_{2}-\cdots-A_{k}\right)$. Here $u_{t}$ 's are assumed to be identically distributed and independent as a multi-normal distribution with zero mean and $\delta$ variance. As we have assumed that there are three variables in $Y_{t}=$ $\left[W_{t}, X_{t}, Z_{t}\right]$, so, we need to examine $3 \times 3 \Pi$ matrix. In Equation (3), $\Pi$ matrix contains information about the long-run equilibrium relationship. The information matrix $(\Pi)$ can be decomposed into $\Pi=\alpha \beta$ where $\alpha$ includes the speed of adjustment to achieve the long-run equilibrium level while $\beta$ is the long-run matrix of coefficients. Therefore, the $\beta Y_{t-1}$ term is equivalent to error correction term $\left(Y_{t-1}-\beta-\beta_{1} X_{t-1}\right)$ in case of two variables model, except the fact that here $\beta Y_{t-1}$ contains up to $(n-1)$ vectors in a multivariate framework. For simplification reasons, we assume that there are only two lags $(k=2)$, the model can be 
presented as follows:

$$
\left(\begin{array}{c}
\Delta W_{t} \\
\Delta X_{t} \\
\Delta Z_{t}
\end{array}\right)=\Gamma_{1}\left(\begin{array}{c}
\Delta W_{t-1} \\
\Delta X_{t-1} \\
\Delta Z_{t-1}
\end{array}\right)+\Pi\left(\begin{array}{c}
W_{t-1} \\
X_{t-1} \\
Z_{t-1}
\end{array}\right)+e_{t} .
$$

Equation (4) can also be written as follows:

$$
\left(\begin{array}{c}
\Delta W_{t} \\
\Delta X_{t} \\
\Delta Z_{t}
\end{array}\right)=\Gamma_{1}\left(\begin{array}{c}
\Delta W_{t-1} \\
\Delta X_{t-1} \\
\Delta Z_{t-1}
\end{array}\right)+\left(\begin{array}{ll}
\alpha_{11} & \alpha_{12} \\
\alpha_{21} & \alpha_{22} \\
\alpha_{31} & \alpha_{32}
\end{array}\right)\left(\begin{array}{lll}
\beta_{11} & \beta_{21} & \beta_{31} \\
\beta_{12} & \beta_{22} & \beta_{32}
\end{array}\right)\left(\begin{array}{c}
W_{t-1} \\
X_{t-1} \\
Z_{t-1}
\end{array}\right)+e_{t} .
$$

In Equation (5) the error correction part (i.e., for $\Delta W_{t}$ on LHS) can be analyzed by the following equation:

$$
\Pi_{1} Z_{t-1}=\left(\left[\alpha_{11} \beta_{11}+\alpha_{12} \beta_{12}\right]\left[\alpha_{11} \beta_{21}+\alpha_{12} \beta_{22}\right]\left[\alpha_{11} \beta_{31}+\alpha_{12} \beta_{32}\right]\right)\left(\begin{array}{c}
W_{t-1} \\
X_{t-1} \\
Z_{t-1}
\end{array}\right),
$$

where $\Pi_{1}$ is the first row of the $\Pi$ matrix, and the above Equation (6) can also be written as follows:

$$
\Pi_{1} Z_{t-1}=\alpha_{11}\left(\beta_{11} W_{t-1}+\beta_{21} X_{t-1}+\beta_{31} Z_{t-1}\right)+\alpha_{12}\left(\beta_{12} W_{t-1}+\beta_{22} X_{t-1}+\beta_{32} Z_{t-1}\right) .
$$

Equation (7) clearly shows the cointegrating vectors with $\alpha_{11}$ and $\alpha_{12}$ terms of their respective speed of adjustment.

In order to test the rank of $\Pi$ matrix, Johansen ${ }^{[57]}$ developed a reduced-rank regression procedure. Johansen and Juselius ${ }^{[1]}$ explained two methods that could determine the number of cointegration equations and both involve estimation of $\Pi$ matrix. The first method proposed by Johansen is maximum eigenvalue statistics denoted by $\lambda_{\max }$. The test consists of ordering the largest eigenvalue in descending order and considering whether they are significantly different from zero. To test how many of the numbers of characteristics roots are significantly different from zero this test uses the following statistics:

$$
\lambda_{\max }(r r+1)=-T \ln \left(1-\lambda_{r+1}\right) .
$$

The second method proposed by Johansen is based on likelihood ration test about the trace of the matrix and that is why, it is known as trace test. The trace test considers whether the trace is increased by adding more eigenvalue beyond the $r$ th eigenvalue. The null hypothesis in this case is that "the number of cointegrating vectors is less than or equal to $r$ ". This test-statistic value is calculated by

$$
\lambda_{\text {trace }}(r)=-T \sum_{t=r+1}^{n} \ln \left(1-\lambda_{r+1}\right) .
$$

Critical values for both statistics are provided by Johansen and Juselius ${ }^{[1]}$. Once it is decided that the long-run relationship between stock prices index and financial economics variables exists, then we adopt the bivariate VAR model to estimate granger causality relationship. For 
further investigation in this pairwise granger causality, two-way causation of variables, say $X$ and $Y$ can be tested. The following bivariate regression is used where $X$ granger causes $Y$ and $Y$ granger causes $X$

$$
\begin{aligned}
& Y_{t}=\alpha_{0}+\alpha_{1} Y_{i-1}+\cdots+\alpha_{n} Y_{i-k}+\beta_{1} X_{i-1}+\cdots+\beta_{n} X_{i-k}+\varepsilon_{t}, \\
& X_{t}=\alpha_{0}+\alpha_{1} X_{i-1}+\cdots+\alpha_{m} X_{i-1}+\beta_{1} Y_{i-k}+\cdots+\beta_{m} Y_{i-k}+u_{t} .
\end{aligned}
$$

The calculated F-statistics is used to accept or reject the hypothesis. The first regression equation (10) is used to test the hypothesis "macroeconomic economic variables, say $X$ does not granger cause the stock prices index say $Y$ " and the second regression equation (11) is used to test the hypothesis "stock prices index does not granger cause the macroeconomic economic variables".

\section{Empirical Estimation}

\subsection{Unit Root and Multivariate Cointegration Tests}

In order to check the stationarity of data series, we employ two different unit root tests; Augmented Dickey Fuller and Phillip-Perron, and results for both these tests are reported in Table 2. The results indicate that all the variables are stationary at first difference. Once it is confirmed from the unit root tests that all the series are integrated at same order $I(1)$, we then proceed further to estimate a multivariate Johansen and Juselius ${ }^{[1]}$ cointegration test to analyze the equilibrium relationship between stock prices and other financial variables. The results of multivariate cointegration tests are presented in Table 3 . The results of trace test in panel-3A of Table 3 indicate that the selected variables have at least one cointegrating equation, and support the rejection of null hypothesis that there is no cointegration between the variables whereas max-eigenvalue test in panel-3B does not show any cointegrating vector at $5 \%$ significance level.

Following Lüutkepohl, et al. ${ }^{[60]}$, who documented that trace test-statistic, has more superior power to that of max-eigenvalue test, there is significant evidence that stock market, money market and foreign exchange market have long-run equilibrium relationship. Therefore, we carry on our further analysis on the basis of trace test-statistic in multivariate cointegration test.

\subsection{Vector Error Correction Model (VECM) and Granger Causality Test}

Since the international markets are strongly integrated due to advance technology in this age of globalization it is quite possible that local markets can also be influenced significantly by the external forces. Therefore we have considered a 15-years monthly data that consist on local macroeconomic variables and foreign exchange rate as an external variable to analyze the impact internal and external factors on the stock prices in Pakistan. If we look into the economic history of Pakistan and rest of the world, there are many ups and downs augmented by various economic and financial crises as well as natural catastrophes over the years. Such ups and downs most likely create disequilibrium in the local and international markets. But, the impact of such shocks on the markets remains for short time, while over the long-run period it becomes normal. This can be a very useful point to note for policy makers and financial analysts to make more precise and accurate forecasting and to take necessary action in case of any uneven 
situation in the markets. The relationship between stock market, money market and foreign exchange has been observed very strong and consistent for the long-run time period ${ }^{[11,12,48]}$. But the strong integration of these markets can also pose an adverse impact on the economic stability if any one of these markets is redirected.

Table 2 Unit root tests

\begin{tabular}{cccccc}
\hline \multirow{2}{*}{ Variables } & \multicolumn{2}{c}{ Augmented Dickey Fuller (ADF) } & & \multicolumn{2}{c}{ Phillips-Perron (PP) } \\
\cline { 2 - 3 } \cline { 5 - 5 } & At Level & At First Difference & & At Level & At First Difference \\
\hline \multirow{2}{*}{ KSE-100 } & -1.5281 & $-12.8456^{*}$ & & -1.5822 & $-12.8456^{*}$ \\
M2 & -0.0102 & $-18.6847^{*}$ & & -0.3134 & $-18.2730^{*}$ \\
TBR & -1.2948 & $-11.0283^{*}$ & & -1.5237 & $-11.5736^{*}$ \\
ER & -1.7015 & $-9.1489^{*}$ & -1.7294 & $-9.2685^{*}$ \\
\hline
\end{tabular}

*significant at $\alpha=1 \%$, Source: The results presented in Table 2 are author's own estimates based on the CEIC global database.

Table 3 Johansen cointegration test results for (KSE-100, M2, TBR and ER)

\begin{tabular}{|c|c|c|c|c|}
\hline \multicolumn{5}{|c|}{ Panel-3A Unrestricted Cointegration Rank Test (Trace) } \\
\hline \multicolumn{2}{|c|}{ Hypothesis } & \multirow{2}{*}{ Trace Test } & \multirow{2}{*}{$5 \%$ Critical Value } & \multirow{2}{*}{ P-Value } \\
\hline \multicolumn{2}{|c|}{$H_{0} H_{1}$} & & & \\
\hline$r \leq 0$ & $r>0$ & $51.0785^{*}$ & 47.8561 & 0.0241 \\
\hline$r \leq 1$ & $r>1$ & 24.3318 & 29.7970 & 0.1868 \\
\hline$r \leq 2$ & $r>2$ & 6.4921 & 15.4947 & 0.6373 \\
\hline$r \leq 3$ & $r>3$ & 0.9383 & 3.8415 & 0.3327 \\
\hline \multicolumn{5}{|c|}{$\begin{array}{c}\text { Trace test indicates } 1 \text { cointegrating equations(s) at } 5 \% \text { significance level, }{ }^{*} \text { denotes the rejection o } \\
\text { null hypothesis "there is no cointegration equation" at } 5 \% \text { significance level. }\end{array}$} \\
\hline \multicolumn{5}{|c|}{ Panel-3B Unrestricted Cointegration Rank Test (Maximum Eigenvalue) } \\
\hline \multicolumn{2}{|c|}{ Hypothesis } & Max-Ejoren Value & $5 \%$ Critical Value & P-Value \\
\hline \multicolumn{2}{|c|}{$H_{0} H_{1}$} & & & \\
\hline$r \leq 0$ & $r>0$ & 26.7468 & 27.5843 & 0.0637 \\
\hline$r \leq 1$ & $r>1$ & 17.8397 & 21.1316 & 0.1360 \\
\hline$r \leq 2$ & $r>2$ & 5.5538 & 14.2646 & 0.6709 \\
\hline$r \leq 3$ & $r>3$ & 0.9383 & 3.8415 & 0.3327 \\
\hline
\end{tabular}

Max-eigenvalue test indicates no co integrating equations(s) at $5 \%$ significance level.

Having established a long-run equilibrium relationship between stock market and monetary variables, it is also important to analyze the speed of adjustment that brings back the equilibrium relationship in long-run. For this purpose, we employ the vector error correction model (VECM) and granger causality test-statistics for the whole sample period and sub-sample peri- 
ods $^{4}$. Due to the concerns that results of VAR models are sensitive to the orthogonalisation ${ }^{[61]}$, we experimented various combinations of given variables in VAR system and the results reported here are the robust with respect to the possible orderings. The results of normalized cointegration coefficients and error correction terms in VECM model are presented in Table 4.

Table 4 Normalized cointegrating coefficients in vecm equations

\begin{tabular}{llllll}
\hline Panel-4A & & \multicolumn{5}{l}{} & \\
\hline Time Periods & KSE-100 & M2 & TBR & ER & C \\
\hline 2000:M1 - & 1.000 & $2.7741^{*}(-0.1669)$ & $-0.0540^{*}(-0.0149)$ & $-4.2644^{*}(-0.501)$ & 14.4448 \\
2015:M12 & & {$[-16.6237]$} & {$[3.6302]$} & {$[8.50447]$} & \\
2000:M1 - & \multirow{2}{*}{1.000} & $1.5846^{*}(-0.4158)$ & $-0.0843(-0.0532)$ & $14.4914^{*}(-3.771)$ & 73.4503 \\
2008:M7 & & {$[-3.8112]$} & {$[1.5836]$} & {$[3.8427]$} & \\
2008:M8 - & \multirow{2}{*}{1.000} & $2.1145^{*}(-0.2710)$ & $-0.0237(-0.0201)$ & $-1.1758(-0.8129)$ & 18.2607 \\
2015:M12 & & {$[-7.8039]$} & {$[1.1772]$} & {$[1.4464]$} & \\
\hline Panel-4B Vector Error Correction Term for Each Equation & & \\
\hline Time Periods & & $\mathrm{D}(\mathrm{KSE}-100)$ & $\mathrm{D}(\mathrm{M} 2)$ & $\mathrm{D}(\mathrm{TBR})$ & $\mathrm{D}(\mathrm{ER})$ \\
\hline 2000:M1 - & $\mathrm{ECT}(-1)$ & $-0.0508^{* *}(0.026)$ & $-0.0089^{*}(0.0026)$ & $-0.3369^{* *}(0.159)$ & $-0.008^{* *}(0.004)$ \\
2015:M12 & & {$[-1.9285]$} & {$[-3.4001]$} & {$[-2.1082]$} & {$[-1.9968]$} \\
2000:M1 - & ECT $(-1)$ & $-0.0322^{* *}(0.014)$ & $-0.0012(0.0013)$ & $0.2149^{*}(0.0819)$ & $0.2149^{*}(0.002)$ \\
2008:M7 & & {$[-2.2274]$} & {$[-0.9121]$} & {$[2.6226]$} & {$[3.4742]$} \\
2008:M8 - & ECT $(-1)$ & $-0.3754^{*}(0.079)$ & $-0.0176^{* *}(0.007)$ & $0.4024(0.4443)$ & $-0.0260^{*}(0.009)$ \\
2015:M12 & & {$[-4.7419]$} & {$[-2.3347]$} & {$[0.9057]$} & {$[-2.6218]$} \\
\hline
\end{tabular}

Note Standard errors in ( ) \& t-statistics in [ ], *Significant at $\alpha=1 \%$ and ${ }^{* *}$ Significant at $\alpha$ $=5 \%$, Source: The results presented in Table 4 are author's own estimates based on the CEIC global database.

The normalized cointegration coefficient of money supply (M2) is positive and significant for full sample period and also for the sub-sample period that may be due to the liquidity effect or the implicit relationship between stock prices and money supply. The positive linkage between money supply and stock prices is supported by $[11,20,38,39]$. The negative and significant coefficients of interest rate for full sample period witness a long-run negative relationship between interest rate and stock prices in Pakistan. Although, the coefficients are insignificant in two sub-sample periods but they are also indicating a negative relationship between interest rate and stock prices. In fact, the stock prices are based on discount rate and expected cash flows. If the interest rate changes are driven by the increased inflation rate, then such increase in interest rate may not have much serious impact on the stock prices because the increased cost of capital of the firms can be compensated by the high price level of commodities in the market. On the other hand, if interest rates are increased by the central bank to control the inflation rate and firms are unable to increase the prices of commodities, then expected cash

\footnotetext{
${ }^{4}$ Although for the estimation of long-run cointegration relationship, the data should be at least 10 years. Here, the data in our analysis for military regime and democratic regime consist on almost 8 years and 7 years respectively. Because our objective in this study is to analyze the differences in short term causality among the variables in two different political governance regimes, therefore, the results may be viewed with caution.
} 
flows of firms will be reduced that will curtail the corporate earnings and will reflect the negative impact of interest rate increment. The results of normalized coefficient for interest rate in cointegrating vectors are partially in line with Hasan and Javed ${ }^{[11]}$ for Pakistan. Humpe and Macmillan ${ }^{[29]}$ have also reported a negative relationship between stock prices and interest rate for US and Japan. Contrary to Ratanapokorn and Sharma ${ }^{[20]}$, a negative cointegration relationship is identified between stock prices and exchange rate for full sample time period and second sample time period (democratic regime). Although, the currency depreciation can serve as a positive stimulus if the trade balance is in surplus, and the results of Ratanapokorn and Sharma ${ }^{[20]}$ also in line to the positive linkage between exchange rate and stock price during the military regime. But in the support of negative connection between exchange rate and stock prices, it is argued that due to political and economic instability, there is a continuous fall in exchange rate against US dollar over the years that increases the input cost, and transmits negative impact on the stock prices. Moore and Wang ${ }^{[22]}$ also reported a negative connection between stock prices and exchange rate for both developed and emerging markets.

For long-run causal relationship between stock market, money market and foreign exchange market, the results of VECM with zero restrictions in Panel-3B are also consistent to the results of cointegration vector in Panle-3A. The negative sign of $\operatorname{ECT}(-1)$ with significant $p$-value in the first vector error correction model (VECM) for all three sample periods in which stock prices are taken as dependent variable, confirms the long-run causality running from money supply, interest rate and exchange rate towards stock prices. Moreover, the significant and negative signs of $\operatorname{ECT}(-1)$ in the VEC model for M2 during full sample period and democratic regime are also evident of long-run causal relationship running for stock prices, interest rate and exchange rate to money supply, while during the military regime error correction term $\operatorname{ECT}(-1)$ is insignificant. Similarly, for interest rate (TBR), the $\operatorname{ECT}(-1)$ is significant and negative during the full sample period while it is positive and significant during the first military regime and positive and insignificant during the democratic regime. In case of exchange rate (ER), $\operatorname{ECT}(-1)$ is also negative and significant during the full sample period while for the military regime it is positive and insignificant and for democratic regime, although it is negative but insignificant. The overall picture from VECM results supports the presence of long-run causality relationship between all the variables during full sample period, whereas for the sub-sample periods these results are only valid for KSE-100 index and money supply.

In order to check short run causal causality, we estimate pairwise granger causality test and results are reported in Table 5. The results of granger causality test show that there are significant differences in the causality relationship across the three sample periods. For example, in case of full sample period there is no short run causality relationship between M2 and KSE100 while during the military regime unidirectional causality moving from M2 to KSE-100 and during the democratic regime there is bidirectional causality between M2 and KSE-100. In case of TBR, the results indicate a unidirectional causality running from TBR to KSE-100 during the full sample period and military regime, while there is no causality in either way during the democratic regime. Similarly, for ER, there is an unidirectional causality running from ER to KSE-100 during the two sub-sample periods but there is no sign of causal connection between ER and KSE-100 during the full sample period. The significant differences in the granger 
Table 5 Pairwise Granger causality summary for KSE-100, M2, TBR and ER (PKR/US\$)

\begin{tabular}{|c|c|c|c|c|}
\hline Null Hypothesis: & Time Periods & $\begin{array}{l}\text { F- } \\
\text { Statistic }\end{array}$ & $\begin{array}{l}\mathrm{P}- \\
\text { value }\end{array}$ & $\begin{array}{l}\text { Causality } \\
\text { Direction }\end{array}$ \\
\hline \multirow{6}{*}{$\begin{array}{l}\text { M2 does not Granger Cause KSE-100 } \\
\text { KSE-100 does not Granger Cause M2 }\end{array}$} & \multirow{2}{*}{ 2000:M1-2015:M12 } & 1.1374 & 0.3229 & \multirow{2}{*}{$\mathrm{M} 2 \neq \mathrm{KSE}-100$} \\
\hline & & 1.7746 & 0.1724 & \\
\hline & \multirow{2}{*}{ 2000:M1-2008:M7 } & $5.9295^{*}$ & 0.0010 & \multirow{2}{*}{$\mathrm{M} 2 \geq \mathrm{KSE}-100$} \\
\hline & & 0.9749 & 0.4083 & \\
\hline & \multirow{2}{*}{ 2008:M8-2015:M12 } & $9.1887^{*}$ & 0.0003 & \multirow{2}{*}{$\mathrm{M} 2=\mathrm{KSE}-100$} \\
\hline & & $6.8590^{*}$ & 0.0018 & \\
\hline \multirow{6}{*}{$\begin{array}{l}\text { TBR does not Granger Cause KSE-100 } \\
\text { KSE-100 does not Granger Cause TBR }\end{array}$} & \multirow{2}{*}{ 2000:M1-2015:M12 } & $7.4362^{*}$ & 0.0008 & \multirow{2}{*}{$\mathrm{TBR} \geq \mathrm{KSE}-100$} \\
\hline & & 0.9353 & 0.3943 & \\
\hline & \multirow{2}{*}{ 2000:M1-2008:M7 } & $2.7811^{* *}$ & 0.0455 & \multirow{2}{*}{$\mathrm{TBR} \geq \mathrm{KSE}-100$} \\
\hline & & 0.8698 & 0.4599 & \\
\hline & \multirow{2}{*}{ 2008:M8-2015:M12 } & 1.3920 & 0.2544 & \multirow{2}{*}{$\mathrm{TBR} \neq \mathrm{KSE}-100$} \\
\hline & & 1.1195 & 0.3314 & \\
\hline \multirow{6}{*}{$\begin{array}{l}\text { ER does not Granger Cause KSE-100 } \\
\text { KSE-100 does not Granger Cause ER }\end{array}$} & \multirow{2}{*}{ 2000:M1-2015:M12 } & 1.7920 & 0.1695 & \multirow{2}{*}{$\mathrm{ER} \neq \mathrm{KSE}-100$} \\
\hline & & 0.9898 & 0.3736 & \\
\hline & \multirow{2}{*}{ 2000:M1-2008:M7 } & $3.6897^{* *}$ & 0.0148 & \multirow{2}{*}{$\mathrm{ER} \geq \mathrm{KSE}-100$} \\
\hline & & 0.2990 & 0.8260 & \\
\hline & \multirow{2}{*}{ 2008:M8-2015:M12 } & $3.6708^{* *}$ & 0.0297 & \multirow{2}{*}{$\mathrm{ER} \geq \mathrm{KSE}-100$} \\
\hline & & 0.3558 & 0.7017 & \\
\hline \multirow{6}{*}{$\begin{array}{l}\text { TBR does not Granger Cause M2 } \\
\text { M2 does not Granger Cause TBR }\end{array}$} & \multirow{2}{*}{ 2000:M1-2015:M12 } & $3.2295^{* *}$ & 0.0418 & \multirow{2}{*}{$\mathrm{TBR} \geq \mathrm{M} 2$} \\
\hline & & 1.3334 & 0.2661 & \\
\hline & \multirow{2}{*}{ 2000:M1-2008:M7 } & $5.3057^{*}$ & 0.0021 & \multirow{2}{*}{$\mathrm{TBR} \geq \mathrm{M} 2$} \\
\hline & & 0.7610 & 0.5189 & \\
\hline & \multirow{2}{*}{ 2008:M8-2015:M12 } & 1.5860 & 0.2110 & \multirow{2}{*}{$\mathrm{TBR} \leq \mathrm{M} 2$} \\
\hline & & $3.8857^{* *}$ & 0.0244 & \\
\hline ER does not Granger Cause M2 & 2000:M1-2015:M12 & $3.2478^{* *}$ & 0.0411 & $\mathrm{ER}>\mathrm{M} 2$ \\
\hline M2 does not Granger Cause ER & 2000:111-2010:1N12 & 1.5059 & 0.2245 & - \\
\hline & 2000:M1-2008:M7 & $2.2866^{* * *}$ & 0.0840 & $\mathrm{ER}=\mathrm{M} 2$ \\
\hline & & $2.1603^{* * *}$ & 0.0982 & 然 \\
\hline & 2008:M8-2015:M12 & 0.3335 & 0.7174 & $\mathrm{ER}<\mathrm{M} 2$ \\
\hline & $2000.1710-2010.10112$ & $3.9892^{* *}$ & 0.0222 & 1012 \\
\hline ER does not Granger Cause TBR & 2000:M1-2015:M12 & $19.1577^{*}$ & 0.0000 & $\mathrm{ER}>\mathrm{TBR}$ \\
\hline TBR does not Granger Cause ER & & 1.0889 & 0.3387 & \\
\hline & 2000:M1-2008:M7 & $13.6651^{*}$ & 0.0000 & TBR \\
\hline & 2000:111-2008:171 & $4.0001^{* *}$ & 0.0101 & $1 \mathrm{Dh}$ \\
\hline & $15: M 12$ & 1.8634 & 0.1617 & $\mathrm{ER}<\mathrm{TBR}$ \\
\hline & $2000.1110^{-2015.10112}$ & $2.6166^{* * *}$ & 0.0791 & $\mathrm{LH}=1 \mathrm{DH}$ \\
\hline
\end{tabular}

Note: $*{ }^{* *}$ and $* * *$ denote the significance level at $1 \%, 5 \%$ and $10 \%$ respectively. Source: The results presented in Table 5 are author's own estimates based on the CEIC global database. 
causality relationship among the rest of macroeconomic variables have also been witnessed in the results which indicate the significance of political governance system in establishing the dynamic linkages of financial markets.

\subsection{Stability Diagnostics and Robustness Test}

To check the stability of recursive residuals of estimated vector error correction model (VECM), we run CUSUM test developed by [62]. The CUSUM test of stability plots the cumulative sum of recursive residuals with $5 \%$ critical lines. The parameters are considered instable if the plot of cumulative sum cross the $5 \%$ critical bound. The CUSUM test-statistic is as follows:

$$
W_{t}=\sum_{i=k+1}^{t} w_{i} / s, \quad t=k+1, k+2, \cdots, T
$$

where, $s=\left[\frac{1}{T-k} \sum_{i=k+1}^{T} w_{i}^{2}\right]^{1 / 2}$ is the unbiased estimate of standard deviation $(\sigma \sim N(0,1))$, $W_{t}$ is the recursive residual with $\mathrm{E}\left(W_{t}\right)=0$ and its distribution is symmetric about zero if disturbances in regression models are symmetric. But, if the coefficient of regression changes then $W_{t}$ tend to diverge from zero mean value line. To test the divergence from the zero line, we assess the behavior of $W_{t}$. The null hypothesis "there is no structural change" is accepted, if $W_{t}$ stays within the pair of $5 \%$ critical lines that pass through the points $\left(k, \pm c_{w} \sqrt{T-k}\right)$ and $\left(T, \pm 3 c_{w} \sqrt{T-k}\right)$, where, $c_{w}$ is the parameter depending on the value of significance level $\alpha$. It is well known that $c_{w}=0.850$ at $10 \%$ significance level, $c_{w}=0.948$ at $5 \%$ significance level and $c_{w}=1.143$ at $1 \%$ significance level (see [62] and [63]). The CUSUM plots for all error correction models are shown in Figure 2.

The graph of cumulative sum of recursive residual lines for all the variables under study in VECM model does not show any sign of structural breaks as the recursive residual lines do not cross the $5 \%$ critical red lines. Therefore, we have not made any extra treatment to the data series in our analysis and the results are based on the original data series in log form. Moreover, we also estimate the multivariate ordinary least square regression model as a robust check. The results of OLS regression model would help to compare the significance and direction of comovement between stock prices and other monetary variables in our study. The multivariate regression model can be specified as follows:

$$
\Delta K S E-100=\beta_{0}+\beta_{1} \Delta M 2+\beta_{2} \Delta T B R+\beta_{3} \Delta E R,
$$

where the $\Delta$ is the operator that denotes the series used in their first difference form because all the series are integrated at order $I(1)$. The results of regression model could be misleading and spurious if we use the non-stationary time series in the multivariate regression analysis.

The results of OLS regression model justify the nature of relationship between stock market index and macroeconomic variables under study in case of Pakistan. Although the results of regression model show that the money supply and interest rate are insignificant variables in relation to stock prices during the full sample period but for exchange rate these results are consistent to the results obtained through vector error correction model (VECM). Similarly, the results of multivariate regression model during the military regime are also consistent with respect to signs of the coefficients while during the democratic regime the results for exchange rate show that exchange rate has positive relationship with KSE-100. The positive connection 
between exchange rate and stock prices is strongly supported by Ratanapakorn and Sharma ${ }^{[20]}$ among others.

Plot of cumulative sum of recursive residuals for DKSE-100

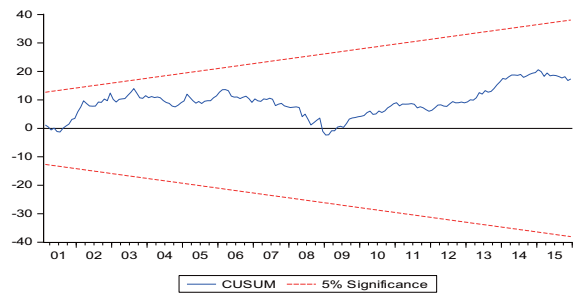

Plot of cumulative sum of recursive residuals for DTBR

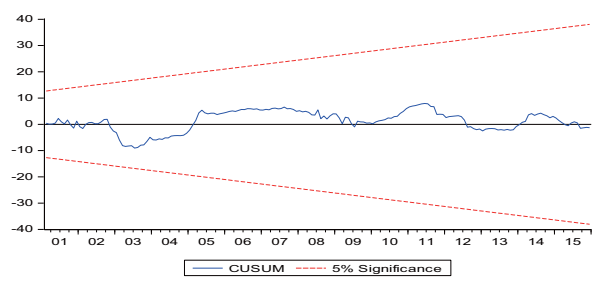

Plot of cumulative sum of recursive residuals for DM2

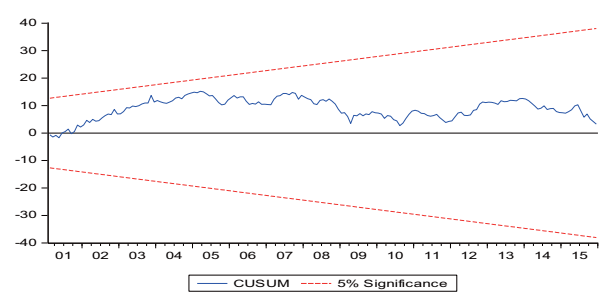

Plot of cumulative sum of recursive residuals for DER

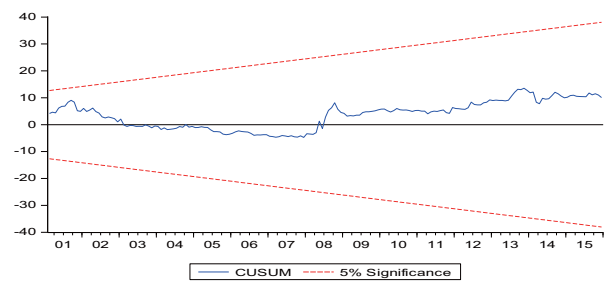

Figure 2 Time series plots of cumulative sum of recursive residuals for vector error correction models (VECM)

Table 6 Results summary of multivariate regression model

\begin{tabular}{cccccc}
\hline Time Period & Variable & Coefficient & SE & t-statistics & $p$-Value \\
\hline & $\beta_{0}$ & 0.0075 & 0.0099 & 0.7565 & 0.4503 \\
2000:M1-2015:M12 & $\beta_{1}$ & 1.0127 & 0.6883 & 1.4713 & 0.1429 \\
& $\beta_{2}$ & -0.0074 & 0.0110 & -0.6740 & 0.5012 \\
& $\beta_{3}$ & $-1.0170^{* *}$ & 0.4455 & -2.2831 & 0.0236 \\
\hline & $\beta_{0}$ & 0.0145 & 0.0149 & 0.9771 & 0.3310 \\
2000:M1-2008:M7 & $\beta_{1}$ & 0.6507 & 0.9862 & 0.6598 & 0.5110 \\
& $\beta_{2}$ & -0.0184 & 0.0158 & -1.1675 & 0.2459 \\
& $\beta_{3}$ & -0.3056 & 0.8043 & -0.3800 & 0.7048 \\
\hline \multirow{2}{*}{ 2008:M8-2015:M12 } & $\beta_{0}$ & -0.0034 & 0.0168 & -0.2016 & 0.8407 \\
& $\beta_{1}$ & 1.0754 & 1.2677 & 0.8483 & 0.3987 \\
& $\beta_{2}$ & $-0.0504^{* *}$ & 0.0229 & -2.1975 & 0.0307 \\
& $\beta_{3}$ & 1.1883 & 0.8782 & 1.3531 & 0.1797 \\
\hline
\end{tabular}

Note: $*, * *$ and $* * *$ denote the significance level at $1 \%, 5 \%$ and $10 \%$ respectively. Source: The results presented in Table 5 are author's own estimates based on the CEIC global database. 


\section{Concluding Remarks}

The cointegration and causality relationship between stock market, money market and foreign exchange market has been established in this study. Unlike the other relevant studies ${ }^{[1,12,64]}$ in Pakistan perspective, we have decomposed the sample period into two sub-samples in order to analyze the significance of good governance in the integration of financial markets in Pakistan. The first sub-sample represents the military regime, whereas the second sub-sample represents the democratic era. Our empirical analysis is based on the multivariate Johansen and Juselius ${ }^{[1]}$ cointegration test, vector error correction model (VECM) and pairwise granger causality tests by using monthly data from 2000:M1 to 2015:M12.

A long-run equilibrium relationship between KSE-100 index and other financial variables is identified by trace test-statistic under the multivariate Johansen-Juselius cointegration analysis for the full sample time period. The coefficients of normalized cointegrating vector show that KSE-100 has positive relationship with M2, while negative with TBR and ER during the full sample and two sub-sample periods only with one exception of ER during the military regime that has a positive connection with the KSE-100. Furthermore, the results of vector error correction model (VECM) for KSE-100 index and other financial variables indicate that there is a significant evidence of long-run causality moving from independent variables to dependent variable in the system of VAR during the full sample periods. Finally, the results of pairwise granger causality test ascertain that M2 does not granger cause KSE-100 and vice versa during the full sample period while there is a unidirectional causality from M2 to KSE-100 during the military regime, and bidirectional causality during the democratic regime. Similarly, there is a unidirectional causality moving from TBR to KSE-100 index during the full sample period and military regime while no causal linkages are identified during the democratic regime. In case of exchange rate, there is a unidirectional causality moving from ER to KSE-100 during the two sub-sample periods while it has no causal connections during the full sample period. Moreover, a strong causality relationship among the other financial variables (M2, TBR and ER) is also witnessed by the results of granger causality tests during all the sample periods.

The overall results are evident that all the three markets are strongly integrated during the full sample period while the results for the two sub-sample periods are more favorable for the democratic regime. The dependence of stock market is more evident during the both military and democratic regime and for the remaining financial variables.

The results of long term causal relationship are more favorable during the democratic regime. It means that markets during the democratic regime are more interdependent as compared to military regime. Only stock market reflects the movement in other financial variables during both regimes otherwise the markets show more close interaction during the democratic regime as compared to military regime. The stock market is strongly driven by the money market and foreign exchange market and vice versa. Therefore, it is important for the investors, portfolio managers and financial analysts to make appropriate decisions by keeping in mind the behavior of money market and foreign exchange market during the different political governance systems. In the same way, the monetary policy makers and regulatory authorities should also set the monetary policy and market regulations accordingly. Based on the results of granger causality, it is important to consider the behavior of exchange rate in order to devise a well-directed 
internal policy regarding stock market and money market that could have the flexibility to absorb these external shocks. As a matter of fact, when markets are strongly cointegrated they can be much sensitive to the behavior of each other and such sensitivity can leave some adverse effects if the dynamics of these markets are not dealt properly.

\section{References}

[1] Johansen S, Juselius K. Maximum likelihood estimation and inference on cointegration — With applications to the demand for money. Oxford Bulletin of Economics and Statistics, 1990, 52(2): 169-210.

[2] Sellin P. Monetary policy and the stock market: Theory and empirical evidence. Journal of Economic Surveys, 2001, 15(4): 491-541.

[3] Thorbecke W. On stock market returns and monetary policy. The Journal of Finance, 1997, 52(2): 635654.

[4] Rigobon R, Sack B. The impact of monetary policy on asset prices. Journal of Monetary Economics, 2004, 51(8): 1553-1575.

[5] Alam M M, Uddin M G S. Relationship between interest rate and stock price: Empirical evidence from developed and developing countries. International Journal of Business and Management, 2009, 4(3): 43-51.

[6] Hayford M D, Malliaris A. Monetary policy and the US stock market. Economic Inquiry, 2004, 42(3): 387-401.

[7] DeGrauwe P. Stock prices and monetary policy. CEPS Working Document No. 304, 2008.

[8] Beenstock M, Chan K F. Economic forces in the London stock market. Oxford Bulletin of Economics and Statistics, 1988, 50(1): 27-39.

[9] Nozar H, Taylor P. Stock prices, money supply, and interest rates: The question of causality. Applied Economics, 1988, 20: 1603-1611.

[10] Mukherjee T K, Naka A. Dynamic relations between macroeconomic variables and the Japanese stock market: An application of a vector error correction model. Journal of Financial Research, 1995, 18(2): 223-237.

[11] Hasan A, Javed M T. An empirical investigation of the causal relationship among monetary variables and equity market returns. The Lahore Journal of Economics, 2009, 14(1): 115-137.

[12] Abbas G, McMillan D G. Interaction among stock prices and monetary variables in Pakistan. International Journal of Monetary Economics and Finance, 2014, 7(1): 13-27.

[13] Bordo M D, Jeanne O. Monetary policy and asset prices: Does 'benign neglect'make sense? International Finance, 2002, 5(2): 139-164.

[14] Cecchetti S G. Asset prices and central bank policy: Centre for Economic Policy Research, ISBN: 1898128537, 2000.

[15] Roubini N. Why central banks should burst bubbles. International Finance, 2006, 9(1): 87-107.

[16] Bernanke B, Gertler M. Monetary policy and asset price volatility. Economic Review, Fourth Quarter: Federal Reserve Bank of Kansas City, 1999.

[17] Bernanke B S, Gertler M. Should central banks respond to movements in asset prices? The American Economic Review, 2001, 91(2): 253-257.

[18] Nieh C C, Lee C F. Dynamic relationship between stock prices and exchange rates for G-7 countries. The Quarterly Review of Economics and Finance, 2001, 41(4): 477-490.

[19] Smyth R, Nandha M. Bivariate causality between exchange rates and stock prices in South Asia. Applied Economics Letters, 2003, 10(11): 699-704.

[20] Ratanapakorn O, Sharma S C. Dynamic analysis between the US stock returns and the macroeconomic variables. Applied Financial Economics, 2007, 17(5): 369-377.

[21] Kim K H. Dollar exchange rate and stock price: Evidence from multivariate cointegration and error correction model. Review of Financial Economics, 2003, 12(3): 301-313.

[22] Moore T, Wang P. Dynamic linkage between real exchange rates and stock prices: Evidence from developed and emerging Asian markets. International Review of Economics \& Finance, 2014, 29: 1-11.

[23] Lin $\mathrm{C} \mathrm{H}$. The comovement between exchange rates and stock prices in the Asian emerging markets. International Review of Economics \& Finance, 2012, 22(1): 161-172. 
[24] Granger C W, Huangb B N, Yang C W. A bivariate causality between stock prices and exchange rates: Evidence from recent Asianflu. The Quarterly Review of Economics and Finance, 2000, 40(3): 337-354.

[25] Tabak B M. The dynamic relationship between stock prices and exchange rates: Evidence for Brazil. International Journal of Theoretical and Applied Finance, 2006, 9(8): 1377-1396.

[26] Nieh C C, Yau H Y. The impact of Renminbi appreciation on stock prices in China. Emerging Markets Finance and Trade, 2010, 46(1): 16-26.

[27] Yau H Y, Nieh C C. Testing for cointegration with threshold effect between stock prices and exchange rates in Japan and Taiwan. Japan and the World Economy, 2009, 21(3): 292-300.

[28] Mishra A K. Stock market and foreign exchange market in India: Are they related? South Asia Economic Journal, 2004, 5(2): 209-232.

[29] Humpe A, Macmillan P. Can macroeconomic variables explain long-term stock market movements? A comparison of the US and Japan. Applied Financial Economics, 2009, 19(2): 111-119.

[30] Chen N F, Roll R, Ross S A. Economic forces and the stock market. Journal of Business, 1986, 59(3): 383-403.

[31] Fama E F. Stock returns, real activity, inflation, and money. The American Economic Review, 1981, 71(4): $545-565$.

[32] Fama E F. Stock returns, expected returns, and real activity. The Journal of Finance, 1990, 45(4): 10891108.

[33] Fama E F, French K R. Business conditions and expected returns on stocks and bonds. Journal of Financial Economics, 1989, 25(1): 23-49.

[34] Schwert G W. Stock returns and real activity: A century of evidence. The Journal of Finance, 1990, 45(4): $1237-1257$.

[35] Black A, Fraser P, MacDonald R. Business conditions and speculative assets. The Manchester School, 1997, 65(4): 379-393.

[36] Ferson W E, Harvey C R. The variation of economic risk premiums. Journal of Political Economy, 1991, 99(2): 385-415.

[37] Hashemzadeh N, Taylor P. Stock prices, money supply, and interest rates: The question of causality. Applied Economics, 1988, 20(12): 1603-1611.

[38] Abdullah D A, Hayworth S C. Macroeconometrics of stock price fluctuations. Quarterly Journal of Business and Economics, 1993, 32(1): 50-67.

[39] Maysami R C, Koh T S. A vector error correction model of the Singapore stock market. International Review of Economics \& Finance, 2000, 9(1): 79-96.

[40] Shostak F. Money and the stock market: What is the relation? Mises Institute, Austrian Economics, Freedom and Peace: Mises Daily Articles, 29 August, 2006.

[41] Apergis N, Eleftheriou S. Interest rates, inflation, and stock prices: The case of the Athens Stock Exchange. Journal of Policy Modeling, 2002, 24(3): 231-236.

[42] Bahmani-Oskooee M, Sohrabian A. Stock prices and the effective exchange rate of the dollar. Applied Economics, 1992, 24(4): 459-464.

[43] Choi J J, Elyasiani E, Kopecky K J. The sensitivity of bank stock returns to market, interest and exchange rate risks. Journal of Banking \& Finance, 1992, 16(5): 983-1004.

[44] Dominguez K M, Tesar L L. A re-examination of exchange rate exposure. NBER Working Paper No. 8128, 2001.

[45] Chkili W, Nguyen D K. Exchange rate movements and stock market returns in a regime-switching environment: Evidence for BRICS countries. Research in International Business and Finance, 2014, 31: $46-56$.

[46] Lee C H, Doong S C, Chou P I. Dynamic correlation between stock prices and exchange rates. Applied Financial Economics, 2011, 21(11): 789-800.

[47] Yang Z, Tu A H, Zeng Y. Dynamic linkages between Asian stock prices and exchange rates: New evidence from causality in quantiles. Applied Economics, 2014, 46(11): 1184-1201.

[48] Wong W K, Khan H, Du J. Money, interest rate, and stock prices: New evidence from Singapore and the United States. U21 Global Working Paper No. 007/2005, 2005.

[49] Tsai I C. The relationship between stock price index and exchange rate in Asian markets: A quantile regression approach. Journal of International Financial Markets, Institutions and Money, 2012, 22(3): 
609-621.

[50] Maysami R C, Howe L C, Hamzah M A. Relationship between macroeconomic variables and stock market indices: Cointegration evidence from stock exchange of Singapore's All-S sector indices. Jurnal Pengurusan, 2004, 24(1): 47-77.

[51] Granger C W. Some properties of time series data and their use in econometric model specification. Journal of Econometrics, 1981, 16(1): 121-130.

[52] Engle R F, Granger C W. Co-integration and error correction: Representation, estimation, and testing. Econometrica, 1987, 55(2): 251-276.

[53] Stock J H. Asymptotic properties of least squares estimators of cointegrating vectors. Econometrica, 1987, 55(5): 1035-1056.

[54] Dolado J J, Jenkinson T, Sosvilla-Rivero S. Cointegration and unit roots. Journal of Economic Surveys, 1990, 4(3): 249-273.

[55] Perman R. Cointegration: An Introduction to the Literature. Journal of Economic Studies, 1991, 18(3): $3-29$.

[56] Hamilton J D. Time series analysis. Princeton University Press, Princeton, 1994.

[57] Johansen S. Statistical analysis of cointegration vectors. Journal of Economic Dynamics and Control, 1988, 12(2): 231-254.

[58] Dickey D A, Fuller W A. Distribution of the estimators for autoregressive time series with a unit root. Journal of the American Statistical Association, 1979, 74(366a): 427-431.

[59] Dickey D A, Fuller W A. Likelihood ratio statistics for autoregressive time series with a unit root. Econometrica, 1981, 49(4): 1057-1072.

[60] Lüutkepohl H, Saikkonen P, Trenkler C. Maximum eigenvalue versus trace tests for the cointegrating rank of a VAR process. The Econometrics Journal, 2001, 4(2): 287-310.

[61] Brooks C, Tsolacos S. The impact of economic and financial factors on UK property performance. Journal of Property Research, 1999, 16(2): 139-152.

[62] Brown R L, Durbin J, Evans J M. Techniques for testing the constancy of regression relationships over time. Journal of the Royal Statistical Society, Series B (Methodological), 1975: 149-192.

[63] Johnston J, DiNardo J E. Econometric methods. McGraw Hill, New York, 1984.

[64] Attari M I J, Safdar L, Student M. The relationship between macroeconomic volatility and the stock market volatility: Empirical evidence from Pakistan. Pakistan Journal of Commerce and Social Sciences, 2013, 7(2): 309-320. 